\title{
The Role of Demarketing in Reducing Electricity Demand
}

\author{
Mahmood Jasim AL-Samydai ${ }^{1} \&$ Rudaina Othman Yousif ${ }^{1}$ \\ ${ }^{1}$ Department of Marketing; Faculty of Economic and Administrative Sciences, Al-Zaytooneh University of \\ Jordan, Jordan \\ Correspondence: Mahmood Jasim AL-Samydai, Department of Marketing; Faculty of Economic and \\ Administrative Sciences, Al-Zaytooneh University of Jordan. Jordan, Box130, Amman, 11733 Jordan. E-mail: \\ Mahmod_jasim2000@yahoo.com
}

Received: November 2, 2017

Accepted: November 28, 2017 Online Published: December 20, 2017

doi:10.5539/ijbm.v13n1p209

URL: https://doi.org/10.5539/ijbm.v13n1p209

\begin{abstract}
The current study aims to examine the influence of demarketing in reducing the demand for electricity in Jordan. According to (Kotler and Levy. 1971) the demarketing is based on three strategies (general demarketing strategy, selective demarketings strategy and ostensible demarketing strategy). The philosophy of demarketing based on creating better and healthier environment for community and it represents an important tool to determine the consumption of a certain product permanently or temporarily.

Demarketing considered an important tool that is used to limit demand or consumption, or rationalize its use, of a certain product or service, permanently or temporarily (fuel electricity, water, etc.) due to the rarity of these resources and their importance, economically, to countries. It is used to limit the use of some products that damage public heath, society, and community (like smoking, alcohol, controlled medication and narcotics, etc.). This paper shows the benefit from the general demarketing to influence the demand of electricity.

The researchers depended on secondary resources represented by the available literature. In addition, the researcher depended on designing a questionnaire composed of 27 questions that were implemented on a sample of 592 consumers. The information collected was based on a primary exploration study with the purpose of constructing and designing a study model.

Many factors were inserted within study model has been developed according to literatures related to the subject. Thus, this study questionnaire consisted of six dimensions, which are the general demarketing strategy, (advertising, campaigns, perception, price, solar energyand and reference group) and the demand of electricity. The development of six hypotheses was based on the dimensions of the study.

All six hypotheses were accepted as well as the seventh hypothesis, concerning the relationship of the link between the components of the study model. The statistical analysis has shown that the positive correlation between components consisted of strong correlation (positive relationship) between each component of demarketing and the reducing the demand for electricity. Researchers faced number of difficulties while conducting this study. Many consumers do not agree with the questionnaire, there is no clear understanding of the concept of reverse marketing, and there are not many studies that deal with this field. The importance of this study is reflected through the effective role of demarketing that can play in influencing the reducing of demand for electricity, and improve them, towards rationalization of electricity consumption.
\end{abstract}

Keywords: Demarketing, Demand, electricity, advertising campaign, perception, price, reference group

\section{Introduction}

According to (Sullivan \& Steven. 2003) the 'demand' is the quantity of a commodity or a service that people are willing or able to buy at a certain price.

Demand is the consumer's need or desire to own the product or experience the service. It's constrained by the willingness and ability of the consumer to pay for the good or service at the price offered (Kimberly, 2017). Therefore, demarketing workers should head towards influencing the demand of goods and services. There are many problems that face societies in our modern life like environmental problems, harmful behaviors that effects environment badly, increase of power prices and severe shortage in natural resources due to demand increase. (Greene et al., 2004). 
In addition, none programmed consumption of some products that have many effects on society, health and national economy (Zhou et al., 2015). According to the study of (Lucia Athenosy. 2015), energy, water and food are among the most important sources of basic resources, so they must be preserved; and maintaining them requires a trend towards demarketing.

The issue of electricity consumption is a serious and important subject that is located on top of the list, which has great impact on countries' economies especially for those who are not producers of petrol and natural gas. The impact becomes serious, disturbing and painful within severe variations of international petrol markets. It affects, continuously, countries' budgets in a very negative way; where petrol imports' reserves and consumes great amount of money from their budgets. (Kaplan. 2015).

The rationalization of electricity consumption is very important (taking in consideration, it is mainly based on petrol) started from the concept of reducing expenditures on energy including electricity.

Workers in the field of demarketing are working to educate consumers on the importance of reducing the demand of electricity, and maintain on natural resources which will support efforts of preservation of the environment along with national economy and also will contribute in the welfare of the society.

The concept of demarketing is not new, it was initially proposed by Kotler and Levy in 1971 (Dominic. 2001) was the first who used this expression in his researches. Many researchers came after that and tried to phrase definition for it (Alsamydai, 2015).

(Beeton and Pigel. 2003) defined demarketing as an attempt to decrease most or certain types of customers to consume certain product for limited time or permanently, while (Robert Moore. 2005), defined demarketing as an act of discouraging consumption or use of specific product or service, by educating consumers about the importance of reducing demand for the product.

Wall (2007) defined demarketing as a use of marketing hypotheses to convince customers to change their behaviour regarding certain products or services.

In the light of what has been mentioned we may say that demarketing is an attempt for reducing demand on certain product or service. It is done for several reasons, in the following, some of those reasons:

- Organization or Producer capability is not enough to provide or prepare large amounts of product or service in order to meet standing demands.

- Organization or Producer does not wish to provide a certain product or service due to:

- Relative increase in cost of distribution, in a way it does not explain its presenting.

- Decrease in marginal profit.

- Increased cost of marketing

- Rationalize consumption of some high-priced products that considered strain on national economy or rare products or products damaging public and personal health or even irrational consumption of some home products or nutrients. This direction helps to limit product consumption of endangered products. (Kumar. 2010)

- Enhance product quality, as some organizations work to decrease commodity supply, product rarity (usually) indicates high quality in mind of people and consumers. (Stock. 2005).

- Increase product value by decreasing its display and increase the price within the concept that says people need products and services that they feel hard to procure, then they feel glade for procuring it. The rarity and availability of a product in the market indicate its quality. Rarity enhances customers' perceptions of product quality and improves its value.

\subsection{Research Questions}

Some studies found that demarketing applications is used in different areas such as consumptions of water, electricity, smoking, alcohols, controlled medications, narcotics ... etc. It is found that there are limited studies applying the demarketing to impact the demand of electricity. This study will try to provide answers for the following:

- Does the use of demarketing affect the demand of electricity?

- Do advertising campaigns affect the demand of electricity?

- Does people perception affect demand of electricity? 
- Does pricing policy of electricity affect the demand of electricity?

- Does the reference group affect the demand of electricity?

- Does the solar energy, affects the demand of electricity?

\subsection{Study Objective}

Due to the huge amounts of money resulted from electricity consumption, which reflected on payments of the budget, the objective of this research is to know the role of demarketing in reducing the demand for electricity by applying many variables like advertising campaigns, people awareness, pricing policy, reference group and solar energy as alternative power.

\subsubsection{Demarketing Strategies}

There are many strategies for demarketing based on the approach of the study and on researcher tools and objectives. Hypotheses and environment of the study also play a major role to define and choose strategy type. In the following, we will try to provide general explanation for strategy types and tools of decreasing consumption and demand.

\subsubsection{Demarketing Strategy Types}

Creating awareness about necessity to economize and save in irrational consumption behaviour among people is an essential direction in demarketing. This direction in demarketing means and applies a social and cultural change which indicates conversion in social values, habits and consuming patterns away from overconsumption and towards limited and rational consumption. (Medway. 2011) indicated that (Kotlerand Levy. 1971) identified three types of demarketing strategies. (Dharni, 2011; Bradley and Blythe, 2013; Rudaina, 2014; Alsamydai, 2015).

- General Demarketing, which is required when a company wants to shrink the level of total demand.

- Selective Demarketing, which is required when a company wants to discourage demand coming from certain customer levels.

- Ostensible Demarketing, it involves the appearance of discouraging a demand as a device (tool) for actually increasing, both demand and price in later stages. This strategy observed to be implemented by organizations looking towards decreasing demand on a specific product for limited time with the intention to increase its price and create the image of missing the product from markets. This will create an impression in customer's mind regarding product quality, making it valuable and worthy to be owned.

\subsubsection{Tools of Decreasing Consumption and Demand}

According to (Kotler and Levy. 1971), they suggested using the classic tools to reduce consumption and demand (Bradley and Blythe, 2013: Gupta, 2014).

- Curtail advertising expenditures of the product.

- Reduce sales promotion expenditures.

- Increase price and reset other sale conditions.

- Curtail number of distribution outlets.

\section{Literature Review}

Many researchers handled demarketing and its strategies in many aspects, focused in reducing demand in general and reducing the demand of smoking and studies the demarketing effect on lowering this unhealthy, damaging phenomenon, personally and socially, and its impact on society as a whole, which was entitled the sociological impact of attitude towards smoking. (Moore, 2005)

Brian study stated to examine drivers of risky behaviour, such as smoking, among the economical disadvantaged. (Brian, 2006)

Derman focused on demarketing role in controlling and limiting smoking. (Derman, 2008)

Lee study was concerned with smoking phenomenon and its impact on African Americans in United States of America (USA), his study showed that smoking was more prominent in smoking-restricted areas like public areas, parks and restaurants, beside their rejection for tax increase on cigarettes. (Lee, 2004) 
From another dimension of demarketing, many researchers discussed the subject of electricity consumption like (Alqubaili. 2011), he stressed in his study on using insulating material to decrease electrical consumption, and the study concluded that using insulating material, electricity consumption was decreased by $46 \%$.

(Al-Tawoul. 2013) study was about the function of demand on electricity consumption in Gaza strip in order to initiate comparison between the expected electricity that could be saved and the amount of expected consumption. Results of the study concluded that the amount of electricity was insufficient and did not meet the actual demand of the local society.

(Alhmaid. 2012) study focused on specifying employment of practical and architectural ways to decrease and rationalize electricity consumption. The study concluded that electricity was mainly consumed in using air conditioning (cooling and heating) in Iraq.

The aim of (Musdiq and maser. 2012) study was to identify possibility of applying demarketing on electricity consumption to control random and unorganized consumption along with rationalizing its use. The study concluded that demarketing has a major role in electrical consumption in Iraq.

Regarding the use of ostensible demarketing strategy, McKechnie utilized it in his study (British Airways tells Britons do not fly) which was showed by (Bradley and Blythe. 2013).The ostensible demarketing strategy is that, whatever the original intention, the result appears to be the marketing of the product, service or brand is enhanced.

(Ary. 2011) discussed in his study the role of marketing on electricity energy preservation programs in Brazil. His study results confirmed the importance of these programs in decreasing the waste.

(Salman. 2015) study focused on demarketing impact on electricity consumption in Jordan. The most important conclusion of the study was that awareness campaigns for people and increasing electricity price had major role in reasonable electricity consumption. The study found that the most important element that effected electricity consumption was awareness campaigns processed by repetitive advertising laws and civil society organizations.

(Rudaina. 2014) was entitled measuring effectiveness of demarketing in influencing consumer behaviour of people concentrating on water consumption in Jordan.

The study found that there is an impact of demarketing campaigns in water consumption and the effect of following up awareness campaigns carried out by civil society organizations to realize water consumption.

(Alsamydai. 2015) in his study focused on the impact of ostensible demarketing strategy on improving product reputation in customer's mind. The study concluded that there is a positive significant relationship between all the factors considered in the study model, in varying degrees of strength, on improving product reputation in customer's mind.

Many researches tried to connect between demarketing and green marketing, especially green advertising, to the purpose of reducing consumption.

(Atkinson and Rosenthal, 2014; Brandon, 2016)

The study of (Catherine and Brandon. 2016) concentrated to work towards effecting on consumers behaviour by adapting demarketing concept and social responsibility.

This could be achieved by releasing a reversing advertising campaign that focuses on purchasing the trademark, which will have an impact on reducing its consumption for the sack of environment.

\section{Study Model}

The study model designed based on many studies related to the subject, for example (Koschnick. 1995; Robert. 2005; Aanwar. 2008; Zopletalava. 2013; Catherine and Brandon. 2015; Brandona Soul. 2016). Study model consists of the following components:

\subsection{Demarketing Tools}

- Advertising Campaigns: Advertising is the action of calling public attention to something affects behavior, attitude and perception.

- Perception: Perception is conscious sensory experience; it is the process of obtaining information about both external and internal environment with selection of information interpretation and compare them with information possessed by individual along with previous experience to create clear mental image (Alsamydai \& Rudaina, 2005, p 158-165)

- Price Policy: The policy by which a company determines the prices for its products or services. 
- SolarEnergy: Solar energy is radiant light and heat from the sun that is harnessed using a range of ever-evolving technologies such as solar heating, photovoltaic, solar thermal energy, solar architecture, molten salt power plants and artificial photosynthesis (en.wikipedia.org/wiki/Solar energy)

- Reference Group: A reference group is a group whose perspective is taken on by individual, within the group, while forming values, benefits, attitudes, opinion and overt behavior. (Bourne. 1957)

In the following, Figure 1 shows the study module

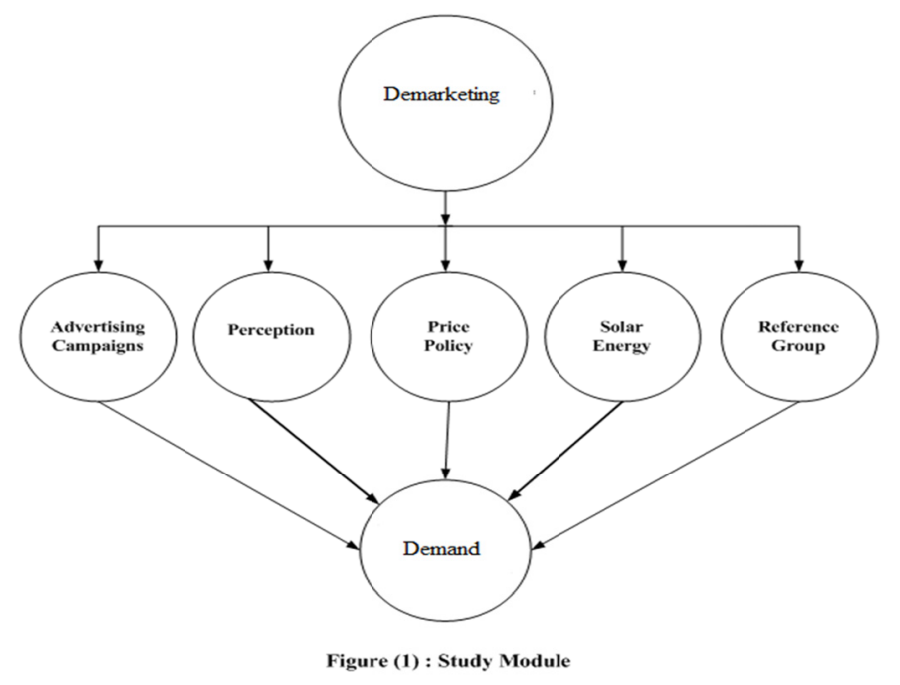

\subsection{Hypotheses of the Study}

The hypotheses of this study were based on study problem, study module and the previous studies in addition to notes and personal experience of the researcher as well as deriving concept of modern marketing and concept of demarketing and its strategies. The hypotheses of the study are:

H1. The use of demarketing affects the demand of electricity

H2. Increase of advertising campaigns affects the demand of electricity

H3. Perception of people affects the demand of electricity

H4. Pricing policy affects the demand of electricity

H5. Solar energy affects the demand of electricity

H6. Reference group affects the demand of electricity

H7.These is as signification relationships between the construct of the study model.

\section{Methodology}

\subsection{Research Design}

The main objective of this research is to study the use of demarketing and its impact on reducing the demand of electricity in Jordan.

More specifically, our research questions aim to examine which factors, and to what extent each of these factors influences the demarketing on reducing the demand. The initial empirical work, using questionnaire as data collection method was deemed appropriate, as they can provide necessary flexibility needied.

\subsubsection{Data Collection and Sampling}

In order to identify relationship among the variables that lead to the use of demarketing to reducing the demand of electricity in Jordan, questionnaires were used as primary data collection method. This questionnaire designed and improved after exhibiting the primary copy with study module and its hypotheses. The society of this study consists of people in Amman, Jordan. The sample used was simple randomized sampling, as questionnaire copies were distributed, answered and collected and makes (a sample space).

\subsubsection{Scale and Dimension of the Study}

Having taking into consideration the criteria for selecting scaling techniques information needed by the study as well as the characteristics of the respondents and the mode of administrating the survey instruments, the five 
point Likert Scale was considered as most appropriate for the current study. Likert scale was used in dimensions 2 and 3 (very agree) to (do not agree strongly). The process of scaling is an essential tool in almost research situation (Malhotra. 2004) and is most commonly used for assessing the way people feel or think about objects or constructs (Neuman. 2003).

\subsection{Validity and measurement of the tool}

The researchers submitted the questionnaire to (18) referees of the university faculty members to verify its validity. Cronbach' Aspha coefficient has been used with a value of Cronbach's Alpha $(\mathrm{a}=0.81)$ for all variable of the study.

Table 1. Reliability coefficient

\begin{tabular}{lll}
\hline No.of cases & Cronbach's Alpha & No. of items \\
\hline 592 & 0.81 & 27 \\
\hline
\end{tabular}

\subsection{The Results}

By using descriptive analysis it was determined that the mean of all questions are over the midpoint (3).

Test results of the set of hypotheses of the study are shown in table (2). Statistical analysis of this illustrates in overall mean score of respondent which measures the (D1, D2, D3, D4, D5 , and D6,) that corresponds the five hypotheses. The mean values of these are $\mathrm{H} 1=3.56, \mathrm{H} 2=3.50, \mathrm{H} 3=4.01, \mathrm{H} 4=3.54$ and $\mathrm{H} 5=4.32, \mathrm{H} 6=4.02$. These values are above the scale midpoint (3).

These results were further validated by one sample t-test which revealed that the overall mean different for these dimensions as whole was statically significant $(\mathrm{N}=0.000)$ AT $(\mathrm{Ns}=0.05)$ with a higher $\mathrm{T}$ value $(\mathrm{H} 1=8.75$, $\mathrm{H} 2=7.64, \mathrm{H} 3=14.03, \mathrm{H} 4=8.63, \mathrm{H} 5=15.92$ and $\mathrm{H} 6=14.62)$ these scores are higher than tabular $+($ tabular=1.96), as a result of five hypothesis are accepted. These results are shown in table 2.

Table 2. Testing hypothesis

\begin{tabular}{|c|c|c|c|c|}
\hline \multirow[t]{2}{*}{ Hypothesis } & \multicolumn{4}{|c|}{ Test value $=3$} \\
\hline & Mean & Std.Der & T.value & Sig2 \\
\hline H1: The use of demarketing, affects the reduction of demand for electricity & 3.56 & .69 & 8.75 & .000 \\
\hline $\mathrm{H} 2$ : Increased advertising campaigns affect the reduction of demand for electricity & 3.50 & .71 & 7.64 & .000 \\
\hline H3: Perception of people affect the reduction of demand for electricity & 4.01 & 69 & 14.03 & .000 \\
\hline H4 : Pricing policy affect the reduction of demand for electricity & 3.54 & .69 & 8.62 & .000 \\
\hline H5: Solar energy affects the reduction of demand for electricity & 4.32 & .63 & 15.92 & .000 \\
\hline H6, reference group affect the reduction of demand for electricity & 4.02 & .74 & 14.62 & .000 \\
\hline mean & 3.83 & 69 & 11.60 & \\
\hline
\end{tabular}

H7.There is a signification relationship between the constructs of the study's model.

In order to test the relationship between the components of the study model, Pearson correlation coefficient was adopted and hypothesis (H6) was developed. There is a significant positive relationship between the constructs of the study model; these results are shown in Table 3.

Table 3. Pearson correlation coefficient

\begin{tabular}{lllllll}
\hline Dimension & D1 & D2 & D3 & D4 & D5 & D6 \\
\hline D1 & 1 & & & & & \\
& .000 & & & & & \\
D2 & .532 & 1 & & & & \\
& .000 & .000 & & & & \\
D3 & .441 & .559 & .1 & & & \\
& .000 & .000 & .000 & & & \\
D4 & .502 & .542 & .471 & 1 & & \\
& .000 & .000 & .000 & .000 & & \\
D5 & .510 & .473 & .383 & .389 & .1 & \\
& .000 & 000. & .000 & .000 & .000 & \\
D6 & .498 & .551 & .451 & .314 & .451 & 1 \\
& .000 & 000 & .000 & .000 & .000 & .000 \\
\hline
\end{tabular}




\section{Discussion and Conclusion}

\subsection{Discussion}

The objective of this study is to identify the effect of marketing in reducing the demand for electricity in Jordan. For this purpose, a study model was developed which included several factors divided into six dimensions: advertising, campaigns, perception, price, reference group and solar energy, within demarketing towards reducing the demand of electricity.

Seven hypotheses have been developed based on the study dimensions.

Data analysis was mainly based on conducting descriptive statistics; extract the means and standard deviation. This was followed by using a one Sample T-Test analysis to examine the sevens hypotheses. The seventh hypothesis was mainly developed to examine the relationship between the different components of the study model. Pearson's correlation coefficient was used to test this hypothesis.

The responses of the sample study to questionnaire questions (27 questions) were all positive as the means for these questions were less than three (midpoint $=3$ ).

Results analysis, according to the first dimensions, indicates that the six dimensions (Agree, for people domain, rationalization of electricity consumption) came with the highest middle mean value (3.83) and $\mathrm{T}$ value equivalent to (11.60).

This indicates that individuals have the ability and positive positions towards rationalization of electricity consumption. This is a good thing, which can be used, in this direction, from concerned authorities like official authorities, organization of civil society, media ...).

As for the first dimension, demarketing affects the reduction of demand for electricity com in the five orders with a middle value (3.56) and $\mathrm{T}$ value equivalent to (8.75)

As for the second dimension, increase advertising, came in the sixth order among the six dimensions with a middle value (3.50) and $\mathrm{T}$ value equivalent to (7.64) which indicates to the importance of the issue of rationalization of electricity consumption is not of great effect although it is very important

As for the third dimension, individuals perception, came in the third order among the six dimensions with a middle value (4.01) and $\mathrm{T}$ value equivalent to (14.03) which indicates to the importance of the issue of rationalization of electricity consumption is not of great effect although it is very important

As for the fourth dimension, Prices came on the last order with middle value (3.54) and T value equivalent to (8.02).

The fifth dimension, solar energy as an alternative energy, came on the first order, it is observed that the middle value (4.32) and $\mathrm{T}$ value equivalent to (15.92). This indicates that people have the desire to convert to the alternative energy. The major problem is the cost of this energy conversion, which forms an obstacle for this direction.

The sixth dimension, reference group affects came on the first order on the second order , it is observed that the middle value (4.02) and $\mathrm{T}$ value equivalent to (14.62). Using One-Sample T-Test analysis, all the six hypotheses of the study have been accepted because their value is greater than the tabular value $\mathrm{T}$ that is equals (1.96).

Concerning the sixth hypothesis, Pearson's correlation coefficient was used. The results indicated that there a positive relation between components of the study model. It is the highest correlation value between advertsing and perception for rationalization of consumption importance, with correlation coefficient $(0.559)$.

Finally, this study made it clear that using demarketing have an impact in the reducing of electricity demand.

\subsection{Conclusion}

Demarketing and its strategies are one of the ways of marketing concept and marketing theory that focused on the consumer, meet his needs and want to meet them in a satisfactory way, thus improve his attachment to the organization and its products. Though demarketing presented by (Kotler \& Levy. 1971), (Dominic. 2001), has not been applied widely despite its importance and its reflection to the whole societies economically, on our daily lives, public health. Among others, through rationalization or decreasing demands for some products or services which have great impact like water, electricity, smoking, energy and unjustifiable use of resources; as well as using this concept in improving product quality in customer's mind. This study is an early attempt to discover and understand the use of demarketing to the reducing of electricity demand and as a trial to understand that side of demarketing. 
This study has shown a positive correlation between study variables which are included in the study model; but this relationship has variable value in the correlation coefficient used. In addition to that, these variables were chosen by distributing them, based on their effect and role, in reducing the demand of the electricity this study is an early attempt to discover and understand the use of demarketing to the reducing of electricity demand. And as a trial to understand that side of demarketing.

These results are very important and have great impact on business organizations and marketers if they are after a wider use of demarketing and its strategies using the study model deployed in this research.

It is considered a comprehensive model with many variables depicting the tools of demarketing and its strategies. In addition, this model helps in understanding the manner in which general demarketing strategy can be used.

Marketers are willing to follow the scientific methodology to apply demarketing concept. This cannot be achieved unless it is used with complete conviction, realization and experience, especially related to temporarily decreasing demand (for a limited period) which means decreasing sales, temporarily, thus reflecting the desire to acquire it. Eventually, it will achieve the purpose of opening new windows of opportunities for other types of problems related to reduction or consumption rationalization of many special products that have an impact on health of people or society or state budget.

\section{References}

Alhmaid, T. (2012). Ways to employ planning and architectural techniques to save electricity. Journal planner and Development, (2), 157-135.

Alsamydai, M. J. (2015). The impact of Ostensible Demarketing strategy on improving product reputation in customer's minds. International Review of Management and Business Research, 4(4 Part 1), 973.

Al-Samydai, M. J., \& Rudaina, O. Y. (2005). Consumer's Behaviour. Dar Al-Manakh for Publishing and Distribution. Amman . Jordan.

Al-Tawoul, N. F. (2013). Estimate Demand Function for Electricity consumption of Domestic sector in Palestine, "The case of Gaza study period from 2000 to 2011". The Islamic University - Gaza - Studies Faculty of Commerce - Department of Economics and Development - Master thesis, P1-137.

Amadeo, K. (n.d.). Demand, Not Money, Makes the World Go Round. Retrieved November 01, 2017, from https://www.thebalance.com/what-is-demand-definition-explanation-effect-3305708

Ary, X. D. A. N. (2011). Marketing and conservation program of Brazilian Electric Power: The Importance of PROCEL (the national Program for Electricity Conservation) The George Washington University IBI Management Issues, P1-30.

Atkinson, L., \& Sonny, R. (2014), "Signaling the Green Sell: The Influence of Eco-Label Source, Argument Specificity, and Product. Involvement on Consumer Trust. Journal of Advertising, 43(1), 33-45. https://doi.org/10.1080/00913367.2013.834803

Beeton, \& Pinge, I. (2003). Casting the holiday Dice, Demarketing Gambling to Encourage Local Tourism. Current issues in Tourism Journal, 6(4), 499-500.

Bourne, F. S. (1957). Group Influence in Marketing and Public Relations. In Likert, R. and Hayes, S. P. (Eds.), Some Applications of Behavioral Research. UNESCO: Paris. Report of a seminar conducted by the Foundation for Research on Human Behavior March 26-27, 1956 in Ann Arbor, Mich., and April 19-20, 1956 at Gould House, Ardsley-on-Hudson, N. Y.

Bradley, N., \& Blythe, J. (2013). Demarketing: Routledge. London and New York: Taylor \& Francis Group.

Brandon, J. R., \& Catherine, A. A. S. (2016). Green Demarketing in Advertisements: Comparing "Buy Green" and "Buy Less" Appeals in Product and Institutional Advertising Contexts. https://doi.org/10.1080/00913367.2016.1214649

Brian, L. B., Michael, K. B., \& Joseph, C. Jr. (2006). A new frontier in the battle against smoking: A exploratory investigation of low-income adult smokers. Journal of Nonprofit \& Public section marketing, 16, $123-147$. https://doi.org/10.1300/J054v16n01_07

Catherine, A. A., \& Brandon, J. R. (2015). Less is more: is a green demarketing strategy sustainable? Journal of Marketing Management, 31, 13-14. https://doi.org/10.1080/0267257X.2015.1059874

Darman, S. S. (2008). The role of Demarketing in the reverse control or curb smoking. Iraqi Journal Administrative Sciences, 24, 1-29. 
Greene, D., Hopson, J., \& Li, J. (2004). Running out of and into oil: analyzing global oil depletion and transition through 2050. Journal of the Transportation Research Board, 1-9.

Gupta, R. K. (2014). Demarketing - tool social good, Aravali Institute of Management, Jodhpur (Rajasthan). In Haig, M. (Ed.), Brand failures: the truth about the 100 biggest branding mistakes of all time. London: Kogan Page Publishers.

Kaplan, Y. A. (2015). Overview of wind energy in the world and assessment of current wind energy policies in Turkey. Renewable and Sustainable Energy Reviews, 43, 562-568.

Koschnick, F. K., Hangleiter, T. H., Song, K. S. (1995). Optically detected magnetic resonance study of an oxygen-vacancy complex in BaFBr.

Kotler, P., \& Sidney, L. (1971). Demarketing yes, determining. Harvard Business Review, 74-80.

Lee, D., Boh, D. C., \& Jennifer, B. (2004). The marketing and demarketing of Tobacco product to low-income African American. Health marketing Quarterly, 22(2), 1-68.

Malhotra, R. N. K. (2004). Marketing research: An applied orientation (4th ed.). Upper Saddle, River, NJ: Prentice Hall.

Medway, D., Gary, W., \& Sheetal, D. (2011). Demarketing places: Rationales and Strategies. Journal of Marketing Management, 27(1-2), 12-142. https://doi.org/10.1080/02672571003719096

Moore, S. R. (2005). The sociological impact of attitude toward smoking secondary effect of the demarketing of smoking. Journal of Social Psychology, 145(6), 703-718.

Musdiq, S. N., \& Maseer, H. A. (2012). Possibility of using of demarketing strategies in the service sector in order to control and /or limit the random and undisciplined consumption of electricity provided in particular and in Kurdistan of Iraq -Duhok Governorate. Tikrit Journal of Administrative and Economic Sciences, (80), $127-150$

Neuman, W. L. (2003). Social research methods: Qualitative and Quantitative approaches (5th ed.). Toronto: Allyn \& Bacon.

Rudaina, O. Y. (2014). Measuring the effectiveness of demarketing in influencing consumer behavior of individuals. International Journal of Business Management \& Research, 4(5), 31-43.

Salman, F. M. (2015). Effect of demarketing on rationalization of electricity consumption in Jordan. Thesis for Master's degree in Marketing, Zarqa University, Jordan.

Stock, A., \& Balachander, S. (2005). The making of a "Hot product": A signaling explanation of marketer's scarcity strategy. Management science, 51(8), 1182-1192.

SullivanO', A., \& Steven, M. S. (2003). The Economic Crisis Lessons of Transportation Companies by Labour Productivity in Baltic and Central and Eastern Europe Countries. Journal of Behavioural Economics, Finance, Entrepreneurship, Accounting and Transport, 2(4), 94-103.

Wall, A. P., (2007). Government "Demarketing" as viewed by its target audience. Marketing intelligence \& planning, 25(2), 123-125.

Zhou, S., Huang, Y., Yu, B., \& Wang, G. (2015). Effects of human activities on the eco-environment in the middle Heihe River Basin based on an extended environmental Kuznets curve model. Ecological Engineering, 76, 14-26.

Zikmund, W. G. (2003). Business Research Methods (8th ed.). Cincinnati, Ohio, South-Western.

\section{Copyrights}

Copyright for this article is retained by the author(s), with first publication rights granted to the journal.

This is an open-access article distributed under the terms and conditions of the Creative Commons Attribution license (http://creativecommons.org/licenses/by/4.0/). 